SHS Web of Conferences 10, 00016 (2014)

DOI: $10.1051 /$ shsconf $/ 20141000016$

C Owned by the authors, published by EDP Sciences, 2014

\title{
Woman as a sexual offender - Reality or myths?
}

\author{
A. Kipane \\ Riga Stradinš̌ University, Latvia
}

\begin{abstract}
The aim of the present paper is to characterize types of female sexual offenders. There exist several typologies for female sexual offenders. The author of the paper comes to the conclusion that female sexual abusers is a reality not only abroad but also in Latvia. In Latvia, this issue is not studied in great depth, thus deeper studies of the theoretical and practical issues related to female sex offenders are necessary. The study of sexual offenders is still a developing, growing, and ever-changing field of research.
\end{abstract}

\section{Introduction}

A number of studies have investigated types of female sexual offenders, Denov states that the major part of males and females in her study reported severe sexual abuse by their mothers. Dobesh writes that females rarely kill or assault strangers or acquaintances. Fallen points out that, in most cases, women sexually abuse children in the family and/or outside it. McCarty reported that slightly more than a half of female perpetrators (52\%) molested females, approximately one third (35\%) molested males, and $10 \%$ of the female offenders molested both- females and males. The results of different studies show that sexually violent behaviour of women can take place with a male accomplice or as a result of regular male dominance.

Sexual offence is defined as any crime that involves sexual intercourse or any other sexual act. The main crimes in this category are rape, assault by penetration, and sexual assault. There are also a range of offence governing sexual activities with children. [Oxford Dictionary of Law, 2009]. It follows that sexual crimes are linked not only to passion but also to violence, anger and power.

Offender is one who has committed a crime [Oxford Dictionary of Law, 2009]. There are different types of offenders - dangerous, first offender, fugitive, juvenile and repeat offenders. Courts and Law Enforcement divide criminals taking into account the possibility of repeating the same kind of offence. There can be distinguished the following types of offenders:

- Sexually oriented offenders. Not being categorized as sexual predators or habitual sex offenders, they have been convicted or plead guilty to a sexual offense. They have a check-in with law enforcement every year for 10 year period.

- Habitual sex offenders are the criminals who have criminal conviction or guilty plea for committing a sexual crime, as well as have a prior sexual charge followed by conviction or guilty plea. They have a check-in with law enforcement every year for 20 year period.

This is an Open Access article distributed under the terms of the Creative Commons Attribution License 4.0, which permits unrestricted use, distribution, and reproduction in any medium, provided the original work is properly cited. 


\section{SHS Web of Conferences}

- Sexual predators are criminals with criminal conviction or guilty plea for committing a sexual crime and there is a likelihood of re-offence. Charges of such offenders involved sexual violence or the court determined them a predator. He must register and notify law enforcement of his residence every 90 days for his lifetime. Law enforcement is required to notify school superintendents, police chiefs, day care operators, and neighbours within 1000 feet of their residence (http://www.mosac.net/default.asp?pageid=1\&deptid=1).

Traditionally, the system of criminal typology distinguishes two groups of features 1) which characterise a potential and nature of personality deforming peculiarities; 2) features which reveal personality development process. The data of the centre "Slava" show that in Latvia, 85\% of sexual offenders are habitual criminals, asocial persons and persons with addiction (http://www.probacija. lv/uploads/petijumi/vpd_petijums_gala_variants.pdf). The study results show that many sex offenders do not stand out of general public. They have families and their sexual relations with their partners are normal. They perceive intimidation, humiliation and degradation of their victims as a gratification.

Clinical psychology consultant Dr. Fisher (the U.K.) denotes that various researches allow us to draw a conclusion, that the typological analysis of sexual offenders provide an opportunity to look at the personality of a criminal as a collective and independent type (http://www.lvportals.lv/index.php? menu $=$ doc \&sub=\&id=212881).

American specialist Salter, Ph.D. in Clinical Psychology, states that offender's conviction about his/her ability to escape punishment becomes stronger, ad he/she frequently perceives it as permission to attack the same victim repeatedly. Thus recurrent offences may indicate particular disposition, pathology and dangerousness. Specialist De Becker describes two type's sexual offender - power-predator and persuasion-predator. Persuasion-predator is a considerably wider type. They look for victims who are psychologically weaker and will submit (Salter, 2004).

Groth \& Birnbaum discriminate two types of child molesters regressed and fixated. According to them fixated child molesters are individuals who used to have adult opposite-sex partners, but transferred their ,,sexual need to less threatening partners (children)” due to different stress factors, e.g. "unemployment, physical disability, or loss of sexual confidence". Groth writes that approximately $51 \%$ of child molesters belong to regressed type. Fixated child molesters are "attracted to children throughout life and constitute $49 \%$ of child molesters" (http://www.mosac.net/default.asp?pageid=1\&deptid=1).

American specialist S.A. Johnson says that there exist two types of sexual offenders 1) opportunistic and impulsive offenders commit their crimes impulsively; 2) predatory offenders whose crimes are preplanned (Johnson, 2007). Eldridge points out that there are two groups of predators 1) continuous and 2) discontinuous predators (Eldrige, 1995).

The scholars Lesniak and Lesniak divide sexual offenders into two groups: aggressive- a large proportion of whom are young people, who being characterized as introverts act cynically and with cruelty; they can be distinguished by their impulsive behaviour. They frequently commit their crimes at night time and in the majority of cases their victims are stranger. Non-aggressive - mostly are extroverts and infantile who have known the victim before committing the crime. Substantial number of assaults have taken place in daylight, almost one third of the perpetrators $(65 \%)$ are alcoholics (Старович 3. 1991).

Wood's study shows that sex offenders who do not suffer from serious psychic disorders or do not have record of violence in their criminal histories "had more instances of domestic violence and incest child abuse" (Wood, 2007).

Sexual maniacs should be distinguished as a separate category, but as the author has not found evidence of women sexual maniacs in both scientific literature and in judicial practice, this type of offenders will not be analyzed in the present paper. 
Int. Conf. SOCIETY. HEALTH. WELFARE.

\section{Characteristics of female sex offenders}

Several of researchers ${ }^{1}$ Chesney-Lind \& Shleden, Daly, Gilfus, Windom indicate that female offenders are more likely to have been victims as children or adults. According to Allen, "of the $65 \%$ females convicted of sexually molesting children, $72 \%$ were sexually abused as children, and out of those, $6 \%$ were sexually abused by female". Of these that were sexually abused as children (36\%), $45 \%$ reported that the sexual abuser was a female. Mendel found similar results.

Wolf states that the female offenders of the sample group tended to carry out sexual crimes 1) with accomplice in half of the cases, 2) a victim's dependency served as a reason for their offensive conduct and offense dynamics in considerably more instances if compared to male sex offenders, 3) like males, women sex offenders exploit several similar cognitive distortions, 4) offenders of both sexes participating in the programme both males and females in the treatment programme applied coercion not physical force, as well as 5) in most cases, the victims were either male or female family members.

In Matthews' study it was found out that " 16 female sexual offenders had a total of 48 victims (20 boys, 27 girls, and 1 adult female). Six of the offenders molested both boys and girls; 11 of the women had engaged in penetration". The given data shows similarities between the crimes committed by both sexes. McCarty stated that slightly more than a half (52\%) "of female offenders molested female, 35 molested males, and 10\% molested both." Matthews, Brown, Hull, \& Panesis et. Also agree that female perpetrators more frequently molest victims of the same sex and the same is true in case of rapes carried out by females.

Allen claims that female sex offenders are less stable and have a critical attitude from their parents, and are with greater experience of devaluations, and disappointments than men. In addition to that, they have been physically abused and perpetrated by their partner more frequently, and also in their marriages were less satisfied with their spouses and more-with their children; talking about their sexual experience- they were more sexually satisfied with a greater number of partners than male perpetrator. Women offenders were more frequently victims of the crimes committed by the assailants of both sexes. They less commonly admit being guilty and less frequently perceive their behaviour as sexually abusive, more frequently claim not being guilty, as well as are hostile against informants. When being caught they less commonly feel sorry or guilty, or feel relieved. Denno reported that female offenders are more likely to have had records of neurological and other biological or psychological abnormalities. Talking about the behaviour of women-offenders, Schwartz and Celini state that they display greater sexual activity, are angrier and more offensive (Johnsons, 2007). Apart from that, Dobesh et. al., claim that in the most cases the victim of female assailants is the sex partner or a child with the scene of crime being their own home, moreover, "females rarely kill or assault strangers or acquaintances".

\section{Typologies of Female Sexual offenders}

There are several typologies for female sexual offenders. Window distinguishes four types of women sex assailants: Psychopathic type I offenders can be characterized by their hostility, poor socialization, impulsiveness, and aggressiveness with no or minimal anxiety. Type II - the secondary or neurotic offenders are frequently similar to type I offenders, but differ with greater anxiety, depression and sense of guilt. Type III is called the over controlled offender who do not admit having any problems and possess a high degree of control. Type IV female offenders are "normal" criminals. They are "hostile and tense, but not impulsive" and have minor psychopathological problems (Windom, 1978).

Sorrel and Master's four types of sexual offences carried out by women include:

1. Forced assault with physical force threats and "physical restraints";

2. The "babysitter," with direct or implied threats to a younger boy by non-relative female;

\footnotetext{
${ }^{1}$ Johnson S.A. Physical abusers and sexual offenders. Forensic and Clinical strategies. - Taylor\&Francis, 2007, p. 129-135.
} 


\section{SHS Web of Conferences}

Table 1. Differences and Commonalities in Female and Male Sexual Offenders' Characteristics.

\begin{tabular}{|l|l|l|}
\hline Age & Female & male \\
\hline Aggressiveness & In adulthood, Rarely juvenile & $\begin{array}{l}\text { Most commonly sexually active age } \\
\text { from 16 to 40. }\end{array}$ \\
\hline $\begin{array}{l}\text { Victims } \\
\text {-age } \\
\text {-relationship }\end{array}$ & In rare cases, aggressiveness is weak & frequently typical aggressiveness \\
-sex & $\begin{array}{l}\text { Children and adult } \\
\text { Young people } \\
\text { Strangers, rarely family member } \\
\text { environment }\end{array}$ & $\begin{array}{l}\text { Both sex - men and women } \\
\text { Most commonly family members } \\
\text { and female victim }\end{array}$ \\
\hline weapons & Outside the family & Within or outside the family \\
& $\begin{array}{l}\text { rarely kill or assault strangers or } \\
\text { acquaintances }\end{array}$ & $\begin{array}{l}\text { Approximately 15\% use a shotgun, } \\
25 \% \text { of victims have heavy bodily } \\
\text { injuries. Kill their victims more } \\
\text { frequently than women. }\end{array}$ \\
\hline
\end{tabular}

3. Incestuous assaults on children committed by relatives;

4. Dominant women abuse with direct physical force intimidating and terrifying adult male victims (Sorrel, Mater, 1982).

For example, Los Angeles Times reports that "K.A. Davis 44-year-old divorced woman from Orange County, California, has been accused of engaging in sex with two boys (under 18 years of age, for about a year and a half) who are youth hockey league teammates of her son. During the course of the investigation, the second victim, who is now over 18 years of age, was located. It is believed that Davis committed the lewd acts about six years ago." (http://latimesblogs.latimes.com/lanow/2011/09/hockeymom-sex-crimes.html).

In McCarty's opinion, there exist the following types of female incest offender:

1. The Independent Abusers perceiving their daughters as a part of themselves abuse their daughters. These are most frequently single mothers with serious emotional problems with an experience of being sexually abused ain their childhood.

2. Co-offender Abuser is a "highly dependent individual with marginal social functioning" who commits a crime together with a dominant male-abuser.

3. Accomplice-Colluded Abuser being highly dependent and more functional than the co-offender "does not actually assault the victim, but either colludes with the abuse or ignores him/her". (McCarty, 1986).

Male and female sexual offenders have both common and different characteristic features. The majority of scholars (Widow, Matthew, Spelt, Allen,) believe that the offenders of both sexes do not significantly differ in the nature of the committed crimes, while Denov argues "that some authors and clinical claim that female sex offending is a rare phenomenon (American Psychiatric Association” [APA]). However, there are several differences to be taken into consideration which are summarized in the Table 1.

\section{Conclusions}

Though large number of sexual offences is carried out by women, this fact has been largely ignored; it is worth examining this matter closer. The absolute majority of sexual crimes are committed by men at sexually active age - from 16 to 40 . According to criminal statistic $75 \%$ of sexual predators are males and $25 \%$ are females. Court Information System data on convicted person who have committed sexual offenses in the period 2004-2011 shows that a total of 779 people were convicted for sexual assaults 
Int. Conf. SOCIETY. HEALTH. WELFARE.

including 15 women, or $1.9 \%$ (www.tis.lursoft.lv). According to the data of National Probation Service of Latvia, approximately 5-20\% of all sexual abuses are carried out by women (www.probacija.lv).

Women - sexual abusers are reality not only abroad but also in Latvia. In Latvia, this issue is not studied in great depth thus there are required deeper studies of the theoretical and practical issues related to female sexual offenders. The study of sex offenders is still a developing, growing, and ever-changing field of research.

\section{References}

[1] American Psychiatric Association. Diagnostic and Statistical Manual of Mental Disorder. http://www.psychiatry.org/publications

[2] Eldrige H. Apology and Forgiveness. In A.C. Salter Transforming Trauma: A guide to Understanding and Treating Adult Survivors of Child Sexual Abuse, Newbury Parks, California: Sage, 1995

[3] Hockey mom accused of having sex with son's underage teammates. http://latimesblogs. latimes.com/lanow/2011/09/hockey-mom-sex-crimes.html

[4] Johnson S.A. Physical abusers and sexual offenders. Forensic and Clinical strategies. Taylor\&Francis, 2007, p. 119

[5] McCarty L.M. Mother-child incest: Characteristics of the offender. Child Welfare, 1986, 65, 447458

[6] Mosac: Mothers of sexually abused children http://www.mosac.net/default.asp?pageid= $1 \&$ deptid=1

[7] Oxford Dictionary of Law/edited by E.A. Martin - New York: Oxford University PressInc, 2009, p. 257

[8] Salter A. Predators: Paedophiles, Rapists, and Other Sex Offenders. United States by Basic Books, Perseus Books L.L.C., 2004

[9] Sorrel, P.M. \& Masters, W.H.. Sexual assault on men by women. Archives of Sexual Behaviour, 1982, 11

[10] 117-131

[11] Windom, C.S. (1978). Towards an understanding of female criminality. Progress in Experimental Psychology Research, 1978, 8, 245-308

[12] Wood, J. Risk typologies of serious harm offenders managed under MAPPA: Mental health, personality disorders, and self-harm as distinguishing risk factors. Journal of Forensic Psychiatry \& Psychology, 2007, 18(4), 470-481

[13] Bārtulis J., Nevis izstumt, bet palīizēt laboties. http://www.lvportals.lv/index.php?menu=doc\& sub $=\& i d=212881$

[14] Pētījums "Latvijas un citu valstu pieredze darbā ar seksuālajiem noziedzniekiem.". http://www.probacija.lv/uploads/petijumi/vpd_petijums_gala_variants.pdf

[15] Tiesu informācijas sistēma - www.tis.lursoft.lv

[16] Valsts Probācijas dienests: http://www.probacija.lv/page.php?id=586

[17] Старович 3. Судебная сексолгия. Пер. с польск. - М.: Юридическая литература., 1991 